\title{
Inquiry-driven Teaching \& Learning Using the Archaeal Microorganism Halobacterium NRC-1
}

Article in The American Biology Teacher · January 2016

DOI: 10.1525/abt.2016.78.1.7

CITATIONS

0

6 authors, including:
READS

235

\section{Priya Dassarma}

University of Maryland, Baltimore, School of M... 58 PUBLICATIONS 747 CITATIONS

SEE PROFILE

Wolf T Pecher

University of Baltimore

17 PUBLICATIONS 112 CITATIONS

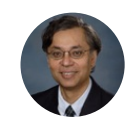

Tony Phillips

36 PUBLICATIONS 564 CITATIONS

SEE PROFILE

SEE PROFILE

SEE PROFILE

Some of the authors of this publication are also working on these related projects:

My Carbon Footprint View project

All content following this page was uploaded by Wolf T Pecher on 27 January 2016.

The user has requested enhancement of the downloaded file. All in-text references underlined in blue are added to the original document and are linked to publications on ResearchGate, letting you access and read them immediately. 
Nor

\section{BIOLOGY TEACHER}

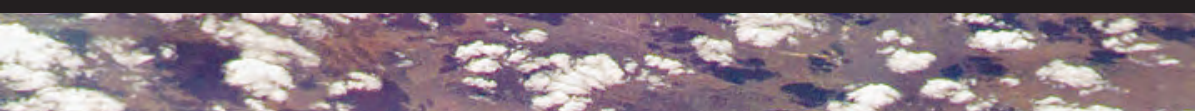

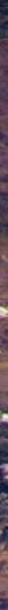

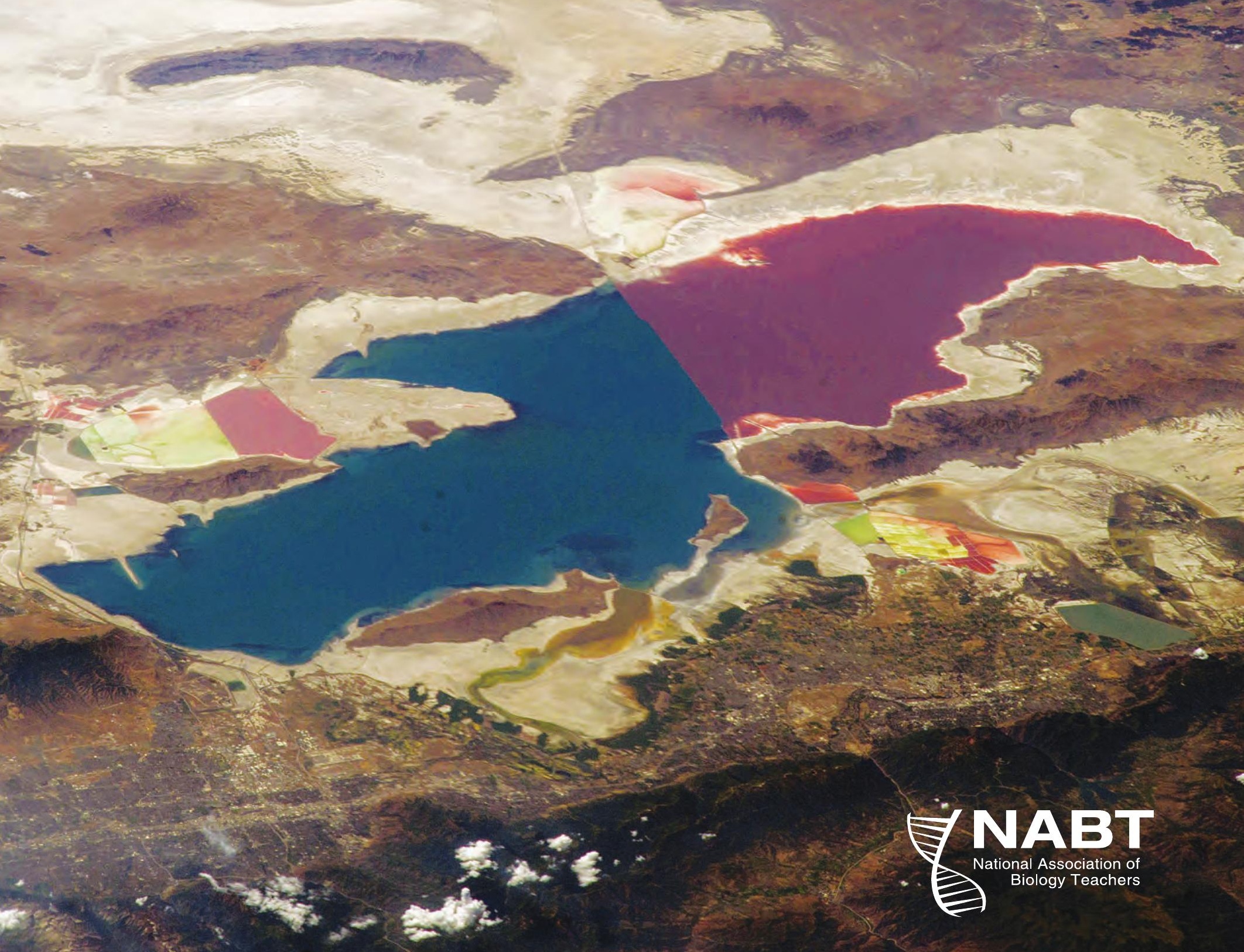




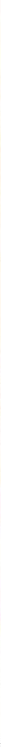

\section{Abstract}

Access to microorganisms in the classroom is essential for teaching fundamental concepts of life sciences, yet most are neither safe nor accessible for classroom instruction. Halobacterium NRC-1, a member of the Domain Archaea, is ideal for engaging students through inquiry-based teaching and learning in the classroom. We introduce this colorful model microbe and provide many ways in which it can be used for experiential learning, including life in extreme environments, basic microbiology skills, action of antibiotics, genotypephenotype connection, genomics and bioinformatics, and applications in biotechnology.

Key Words: Microbiology; halophiles; Haloarchaea; Archaea; laboratory experiments; student projects; extremophiles; hands-on learning.

\section{O Introduction}

Microorganisms are invisible to the naked eye, yet they constitute the numerical majority of life on our planet. They are critical agents in the cycling of elements in the environment as well as in maintaining health, producing foods, and causing infectious diseases. The importance of microorganisms for the Earth's biosphere and to mankind is hard to overemphasize, yet because of their microscopic size and tremendous diversity, fundamental concepts of microbiology are challenging to convey in the classroom. One of the most effective ways to teach microbiology is through experiential, handson, inquiry-based education. Consequently, it is very important to develop safe and engaging microorganisms for the classroom.

Among the diversity of microorganisms

$$
\begin{aligned}
& \text { Microorganisms are } \\
& \text { invisible to the } \\
& \text { naked eye, yet they } \\
& \text { constitute the } \\
& \text { numerical majority } \\
& \text { of life on our planet. }
\end{aligned}
$$

thrive in extreme environments where "normal" life forms could never exist, and they naturally stimulate students' curiosity about the limits to life, the origin of life, and the existence of life elsewhere in the universe. However, because of their "extremophilic" (extremeloving) character, the perception is that these novel microorganisms are not readily available for teaching in the classroom.

Haloarchaea, or salt-loving (halophilic) Archaea, are indeed ideal microorganisms for the classroom. In particular, the Halobacterium strain nicknamed "NRC-1" (from Greek halo, meaning "salt") is an deal teaching microbe (P. DasSarma, 2007; DasSarma \& DasSarma, 2008). First isolated from very salty brine, like the salt pans in San Francisco Bay used to mine salts from the sea (Figure 1), NRC-1 is an excellent experimental organism. Easy methods of DNA extraction and transformation and genetic, genomic, and bioinformatic analysis have been developed for it. NRC-1 has a rich history, as an agent of spoilage of salted food, in early studies of cell buoyancy and motility, and in the identification of the novel, yet ubiquitous, membrane pumps employed for phototrophy (e.g., bacteriorhodopsin; Bayley \& Morton, 1978; DasSarma et al., 2001; P. DasSarma et al., 2010b). Most importantly, NRC-1 has been designated BSL-1 (Biosafety Level-1) and is available for educational uses from Carolina Biological Supply Company (Table 1).

\section{$O$ Introducing Extreme Life in the Classroom}

"Extreme" is a relative term based on an anthropomorphic perspective, and microorganisms known as "extremophiles" are said to tolerate or require environments that humans would not find hospitable, let alone habitable (Table 2; Rothschild \& Mancinelli, 2001). In recent years, microbiologists have discovered extremophiles in nearly every extreme location that has been explored, terrestrial or marine. Some extremophiles have novel properties that have been exploited

The American Biology Teacher, Vol. 78, No 1, pages. 7-13, ISSN 0002-7685, electronic ISSN 1938-4211. C2016 by the Regents of the University of California. All rights reserved. Please direct all requests for permission to photocopy or reproduce article content through the University of California Press's Reprints and Permissions web page, www.ucpress.edu/journals.php?p=reprints. DOI: 10.1525/abt.2016.78.1.7. 


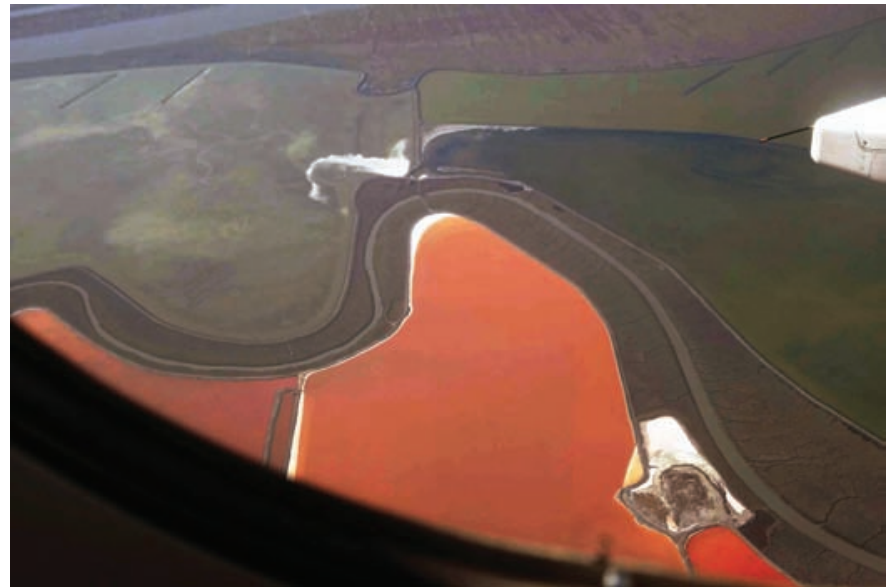

Figure 1. View of San Francisco salterns with colorful bloom of halophiles, as seen from an airplane window. Photo by Priya DasSarma.

Table 1. Teaching resources and uses.

\begin{tabular}{|c|c|}
\hline $\begin{array}{l}\text { Carolina Biological Supply } \\
\text { Resources }\end{array}$ & Classroom \& Project Uses \\
\hline Halobacterium NRC-1 (154800) & Starter liquid culture of NRC-1 \\
\hline $\begin{array}{l}\text { Halobacterium NRC-1 } \\
(154777)\end{array}$ & $\begin{array}{l}\text { Starter culture of NRC-1 } \\
\text { using salt crystals }\end{array}$ \\
\hline $\begin{array}{l}\text { Halobacterium NRC-1 } \\
(154801)\end{array}$ & NRC-1 lawn on a BSYC plate \\
\hline $\begin{array}{l}\text { Introduction to Life in an } \\
\text { Extreme Environment Kit } \\
\text { (154770) }\end{array}$ & $\begin{array}{l}\text { Growing NRC-1 at various } \\
\text { temperatures and media } \\
\text { compositions, in dark vs. } \\
\text { light, UV irradiation; } \\
\text { culturing Haloarchaea from } \\
\text { various sources of salt }\end{array}$ \\
\hline $\begin{array}{l}\text { Basic Microbiology Skills Kit, } \\
\text { Part } 1 \text { (154771) }\end{array}$ & $\begin{array}{l}\text { Learning about sterile } \\
\text { techniques, streaking plates }\end{array}$ \\
\hline $\begin{array}{l}\text { Basic Microbiology Skills Kit, } \\
\text { Part } 2 \text { (154772) }\end{array}$ & $\begin{array}{l}\text { Learning about dilutions and } \\
\text { plating; comparing the } \\
\text { properties of wild-type NRC-1 } \\
\text { and mutants }\end{array}$ \\
\hline $\begin{array}{l}\text { Extremely Easy DNA } \\
\text { Extraction Kit (154773) }\end{array}$ & $\begin{array}{l}\text { DNA extraction and agarose } \\
\text { gel electrophoresis }\end{array}$ \\
\hline $\begin{array}{l}\text { Antibiotics in Action Kit } \\
(154776)\end{array}$ & $\begin{array}{l}\text { Testing effects of } \\
\text { antimicrobial products }\end{array}$ \\
\hline $\begin{array}{l}\text { Genotype-Phenotype } \\
\text { Connection Kit (211217P/ } \\
\text { 211217) }\end{array}$ & $\begin{array}{l}\text { A real research project using } \\
\text { NRC-1, including DNA } \\
\text { extraction, primer design, PCR, } \\
\text { and bioinformatic exercises }\end{array}$ \\
\hline BSYC Agar (775950) & $\begin{array}{l}\text { For making agar plates for } \\
\text { NRC- } 1 \text { and other Haloarchaea }\end{array}$ \\
\hline BSYC Broth (821449) & $\begin{array}{l}\text { For growing liquid cultures } \\
\text { of NRC-1 and other } \\
\text { Haloarchaea }\end{array}$ \\
\hline
\end{tabular}

for applications revolutionizing scientific research and aspects of our daily lives, such as the enzymes of polymerase chain reactions (PCR) used in research, forensics, and medical diagnostics. Among the most easily handled extremophiles in the lab are the Haloarchaea, which are being used for studies as diverse as medical research and astrobiology (S. DasSarma, 2006, 2007; P. DasSarma et al., 2010a).

A main attraction of Halobacterium NRC-1 is that it is a polyextremophile (Slonczewski et al., 2010), tolerating many different extremes: (1) high salinity (three times sea salinity to saturation; Coker et al., 2007); (2) desiccation and entombment in salt crystals, surviving within tiny brine inclusions (Figure 2; Mormile et al., 2003); (3) ionizing radiation, such as cosmic rays and electron beams (Karan et al., 2014); (4) ultraviolet (UV) radiation, both UV-B, causing sunburns in humans at the Earth's surface (Boubriak et al., 2008), and UV-C, a danger to astronauts flying above the ozone layer (Crowley et al., 2006); (5) oxygen deprivation, growing microaerobically or even anaerobically when necessary (DasSarma et al., 2012); and (6) to some degree, temperature, growing in uncomfortable $45^{\circ} \mathrm{C}$ heat and cool $15^{\circ} \mathrm{C}$ temperatures (Coker et al., 2007).

One can readily exploit the traits of NRC-1 to engage students in school and college laboratories. The organism's doubling time ( 6 hours at $42^{\circ} \mathrm{C}$, with shaking at $220 \mathrm{rpm}$ and illumination) is ideal for common class schedules, and it can be varied for convenience by altering the growth conditions employed (e.g., temperature, salinity, nutrients, and aeration). After inoculating liquid Haloarchaea media with salt crystals containing NRC-1, the class can observe the growth of beautiful pink cultures (Figures 2 and 3). Haloarchaeal BSYC medium can be made by dissolving (per liter) $250 \mathrm{~g} \mathrm{NaCl}$, $20 \mathrm{~g} \mathrm{MgSO}_{4} .7 \mathrm{H}_{2} \mathrm{O}, 3 \mathrm{~g} \mathrm{Na}_{3} \mathrm{C}_{6} \mathrm{H}_{5} \mathrm{O}_{7} .2 \mathrm{H}_{2} \mathrm{O}, 2 \mathrm{~g} \mathrm{KCl}, 5$ g yeast extract, and $5 \mathrm{~g}$ casamino acids in water, and adjusting the $\mathrm{pH}$ to 7.2. For agar plates, $20 \mathrm{~g} / \mathrm{L}$ agar is added. Autoclaving is recommended to avoid boiling-over caused by superheating, and a good practice is to fill the flask only halfway. Prepared media and plates can also be purchased (see Table 1). The extremely salty (hypersaline) medium prevents contamination by nearly all other microorganisms, making this first exercise foolproof.

An ideal second hands-on inquiry is to illustrate NRC-l's extremophilic character by growing a liquid culture, allowing it to evaporate to dryness (desiccation), observing the formation of salt crystals, with cells trapped in brine inclusions, and then "reviving" the strain by dissolving the crystals in liquid BSYC media. Subsequently, effects of environmental stressors like UV radiation (using germicidal lamps or sunlight) on cultures can also be addressed. Exposure to changing temperatures, aeration or mixing rates, and variety of nutrients commonly encountered in the microbe's natural environment can be mimicked in the laboratory. Students might address the effects of stressors quantitatively by plating NRC-1 liquid cultures on agar plates with or without exposure to the stressors. Exercises such as these are easily performed using the "Basic Microbiology Skills" or "Life in Extreme Environments" teaching kits, which include manuals with lists of needed materials and detailed protocols (see Table 1 and Basic Microbiology Skills below).

Students can also carry out exercises on the effect of osmotic stress using NRC-1 cells. Looking through a microscope, cells in a drop of NRC-1 liquid culture (on a microscope slide with a coverslip) first appear as slender rods. Upon addition of a drop of tap water at the edge of the coverslip, cells change into pleomorphic forms, including square and triangle, due to a hypotonic effect 
Table 2. Extremes, extremophiles, and their environments.

\begin{tabular}{|l|l|l|}
\hline Extremes & Extremophiles & Environments \\
\hline Hypersalinity & Extreme halophiles & $\begin{array}{l}\text { Grow optimally in }>3.4 \mathrm{M} \text { (20\%) NaCl (e.g., in evaporitic basins } \\
\text { and salterns) }\end{array}$ \\
\hline Heat & Hyperthermophiles & $\begin{array}{l}\text { Temperatures }>80^{\circ} \mathrm{C} \text { (e.g., in geothermal springs of } \\
\text { Yellowstone National Park, Wyoming) }\end{array}$ \\
\hline Cold & Psychrophiles & $\begin{array}{l}\text { Low temperatures, even subzero (e.g., in Antarctic or Arctic } \\
\text { regions) }\end{array}$ \\
\hline Acidity & Barophiles & $\begin{array}{l}\text { High hydrostatic pressures (e.g., in deep oceans, such as } \\
\text { Mariana Trench, New Guinea, }>11 \text { km) }\end{array}$ \\
\hline Alkalinity & Acidophiles & pH <3 (e.g., in acid mine drainage) \\
\hline Lacking oxygen & Alkaliphiles & $\begin{array}{l}\text { Require oxygen-free environments to survive (e.g., cow } \\
\text { rumen and hindguts of termites) }\end{array}$ \\
\hline
\end{tabular}

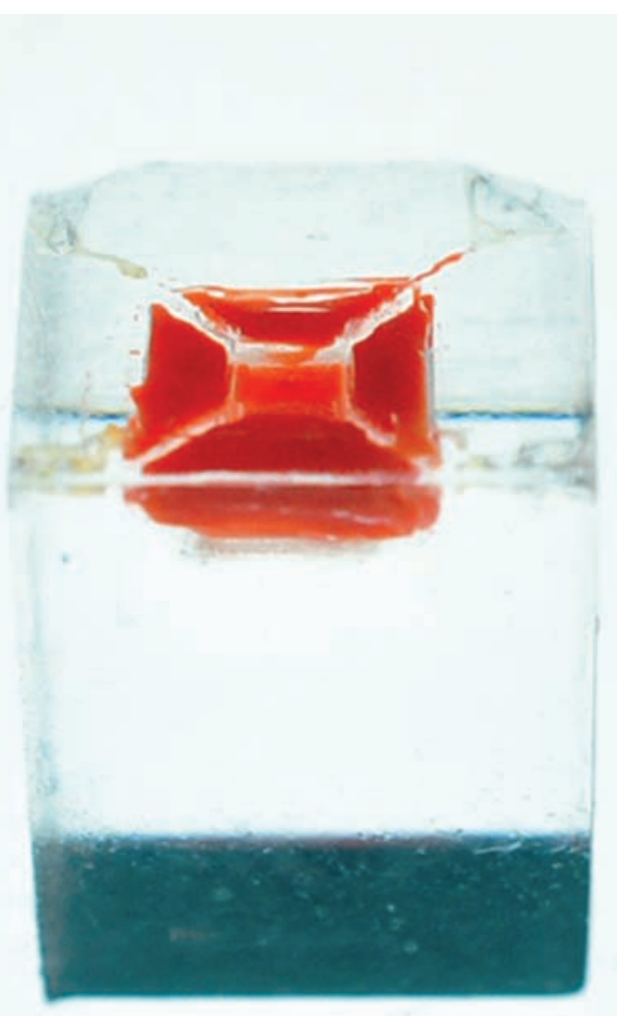

Figure 2. Salt crystal containing Haloarchaea trapped in a large brine inclusion. Photo by Victoria J. Laye.

(deficit of ions) that leads to membrane instability, and an influx of water. With further dilution, NRC-1 cells adopt spherical shape. Ultimately, cells lyse (burst open) when the salinity level drops sufficiently, and then only cell debris remains. The reverse process can also be observed by adding less water; after the hypotonic effect (but not lysis) has occurred, the slide is left to dry a bit, recreating a more saline condition. Cells that have not lysed adopt the rod shape once again, at a rate of appearance dependent on the evaporation rate.

\section{○ Basic Microbiology Skills}

Once introduced to students, Halobacterium NRC-1 serves as an ideal hook for teaching basic microbiology skills. Because many microorganisms are potentially dangerous, knowledge of such skills, including sterile or aseptic techniques, is essential for students. Laboratory procedures for handling, containment, and disposal of pathogenic microorganisms can be demonstrated using NRC-1 as a safe proxy for pathogenic microorganisms. These skills are extremely valuable for students considering careers in food and water safety or in the biotechnology industries, where workers routinely monitor microbial strains and populations; as well as in healthcare, where workers handle sick patients and identify pathogens and antibiotic sensitivity.

As one of the most fundamental lessons, students learn that NRC-1 multiplies by binary fission (splitting of one parent cell into two daughter cells, which can often be observed using a microscope). This leads to exponential growth that can be illustrated in two ways: (1) measuring the optical density (OD) or (2) determining colony-forming units (CFUs). To measure OD, one needs a spectrophotometer or turbidity meter. Students can follow the growth of NRC-1 over a week or longer, depending on culturing conditions. Turbidity is easily apparent to the naked eye and quantified by OD measurements at a visible wavelength (traditionally $600 \mathrm{~nm}$ ), employing sterile media as a blank. Data plotting provides an illustration of exponential or logarithmic growth and, eventually, its limits at stationary phase. Alternatively, during the process of exponential growth, CFUs can be assessed in growing NRC-1 liquid cultures by serially diluting and plating on agar plates. After 7-14 days, the number of resulting colonies can be counted, and the CFUs in the original culture calculated and plotted.

Clonal growth and purification of microorganisms can be illustrated by streaking NRC-1 cells from a liquid culture on BSYC plates using an inoculating loop. Students can also calculate the 

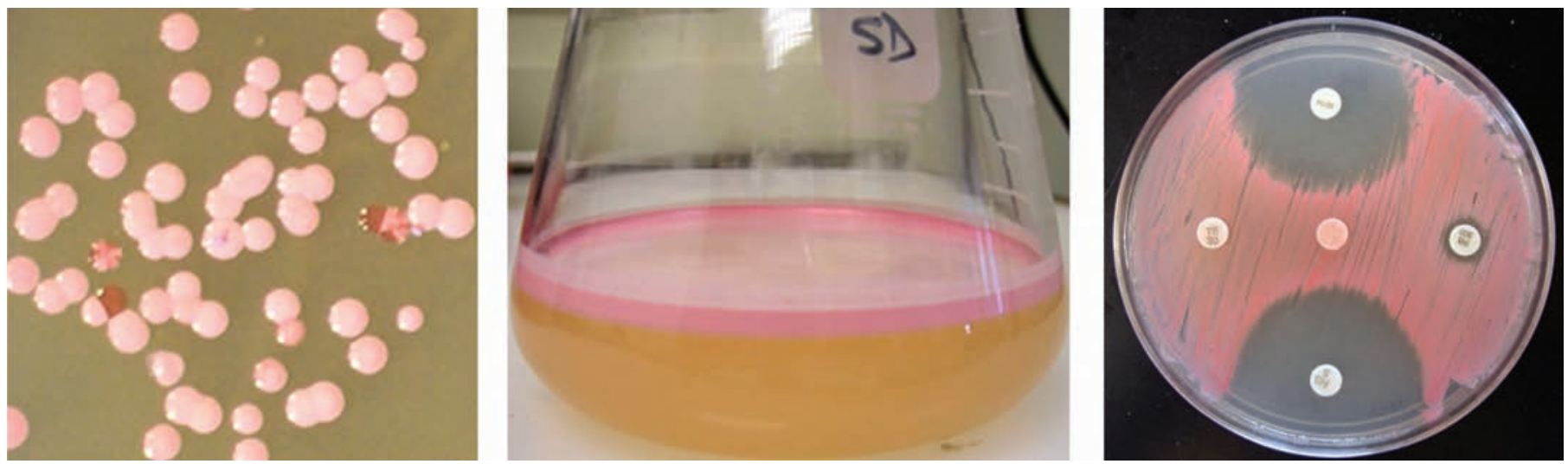

Figure 3. Halobacterium NRC-1. (Left) Colonies grown on a high-salt BSYC-agar plate, with wild-type, pink, opaque colonies outnumbering the mutant, sectored, or red and translucent colonies. (Center) A liquid culture, grown and left to stand, has allowed the buoyant cells to float to the surface. (Right) A lawn of NRC-1 grown on a BSYC-agar plate, with disks of various materials, including antibiotics and controls soaked in BSYC-media or untreated. Zones of clearing due to inhibition or killing of cells are visible. Photos by Priya DasSarma.

number of generations and total number of cells needed to produce a visible colony from a single founder cell. (Note: 25 generations will yield $2^{25}$ or $>33$ million cells, which can be compared to the population growth of other organisms.) These exercises also allow opportunities for use of aseptic (sterile) technique, good pipetting practices, and math skills (including calculating dilutions, plotting and interpreting data), resulting in a wonderful firsthand experience in quantitative microbiology (Table 1).

\section{$\bigcirc$ Antibiotic Sensitivity}

Chemical compounds have been used to treat diseases since ancient times (e.g., herbal remedies), but the term antibiotic was originally used for antimicrobial substances produced by microorganisms. The first antibiotic, penicillin, was discovered by Sir Alexander Fleming on an old Petri plate of Staphylococcus aureus bacteria due to the contaminating mold Penicillium notatum. Today, antibiotics also include many synthetic compounds produced in the laboratory (AmábileCuevas, 2003). Antibiotics may be bactericidal (killing the bacteria) or bacteriostatic (inhibiting microbial cell division), giving the infected host a chance to activate its immune response and clear the infection.

Antibiotic sensitivity can be clearly observed by using NRC-1 in a classic disk-diffusion test (Kirby-Bauer test) with filter disks containing common antibiotics to create an "antibiogram." For example, students could use ampicillin, a penicillin derivative with no effect on NRC-1, or mevinolin, produced by Aspergillus terreus and used as a cholesterol-lowering drug for humans, with no growth-inhibitory effect on bacteria. A teaching kit, "Antibiotics in Action," which yields dramatic zones of clearing in pink lawns of NRC-1, is available for this exercise (Table 1; Figure 3, right panel). Students can readily observe, measure, and compare these zones. They can also test archaeacidal activity of available chemicals around the house or around the school laboratory as an inquiry exercise, making sure that the composition of the solutions placed on filter disks includes high salt concentrations $(>2.5 \mathrm{M} \mathrm{NaCl})$ to avoid osmolytic effects (see above).

While antibiotics have saved countless lives, the emergence of antibiotic-resistant microbes, particularly those resistant to multiple antibiotics ("multidrug resistant" or MDR strains) are a serious concern to public health. Students must be made aware of the causes and consequences of drug resistance, and NRC-1 provides an exceptionally safe organism for such exploration. Drug-resistant mutants are easily isolated by plating large numbers of sensitive NRC-1 cells on antibiotic-containing plates. Once resistant colonies have been observed, students can research mutation rates and mechanisms by plating known numbers of cells onto plates containing antibiotics and calculating the CFUs that appear on the plates. Advanced students can even replicate the classic LuriaDelbrück fluctuation test (Luria, 1975) and determine whether mutants preexist, thus reinforcing their understanding of the mutagenic process. All these exercises can be performed without creating potentially harmful strains, as would be created if using conventional bacteria.

Additional genetic phenomena that have been studied and explored for many years include those leading to gene transfers and genetic recombination. For example, discoveries of conjugation, transduction, and restriction-modification in bacteria led to our modern understanding of recombination and restriction of genetic material. Almost all the techniques used to discover these genetic phenomena can be performed using NRC-1, including cloning, transformation, gene expression, and gene-knockouts employing detailed protocols that are available in DasSarma and Fleischmann (1995), Berquist et al. (2005), and the Carolina kits (Table 1). Although NRC-1 displays highly recombinogenic traits, it does not conjugate, as E. coli and many pathogenic bacteria do. This is a benefit for classroom use where the microbe retains its fundamental genetic character without external influence.

\section{O From DNA Extraction to the Genotype \& Phenotype Connection}

After struggling with dangerous chemicals (e.g., phenol) or buying expensive, single-use kits to extract DNA, it is refreshing to use NRC-1, which rapidly lyses when encountering lower salinity. NRC-1 cannot tolerate the low salinity of seawater $(0.6 \mathrm{M})$ or 
human blood $(0.14 \mathrm{M} \mathrm{NaCl})$. In the classroom, DNA is easily procured by the "splash and spool" method: just add tap water to a lawn of NRC-1 grown on its BSYC-agar plate, loosen lysate, add chilled ethanol, and spool out the sticky, thread-like material. A kit for this exercise, "Extremely Easy DNA Extraction," is available (Table 1). Of course, there are many further steps to completely purify DNA, but at the introductory level, this satisfying demonstration of the universal genetic material can have a great impact on students. This is also an excellent opportunity to discuss Avery, MacLeod, and McCarty's seminal discovery that DNA, not protein, was the "stuff of genes" (transforming principle), relating the extraction methods used, including spooling (McCarty, 1985), the structure of the molecule (double helix), and decoding of the genetic code by Khorana, Nirenberg, and Holley (Khorana, 1972).

One can, even in a school laboratory, use NRC-1 for all the current microbiology techniques imaginable, including DNA extraction, PCR amplification, electrophoresis, DNA sequencing, and bioinformatic analysis. One very interesting way of integrating all these methods in a student research project is to use the "Genotype-Phenotype Connection" kit (Table 1). This kit allows students to replicate classical research on NRC-1 genetics and genomics, which led to the identification of Haloarchaeal insertion sequences (ISH) and genes involved in formation of buoyant gas-vesicle nanoparticles (GVNPs; DasSarma, 1989). Tiny, subcellular nanoparticles, GVNPs are hollow and consist of a rigid, thin protein membrane that prevents infiltration by water but allows uptake of ambient gases. They give NRC1 cells buoyancy for flotation (see Figure 3, center panel) and better access to oxygen (for aerobic respiration) and sunlight (for phototrophy) (DasSarma et al., 2001). GVNPs are football-shaped (also described as lemon- or spindle-shaped; see Figure 4) and give the microbial cultures an opaque, milky-pink appearance due to refraction of light. However, GVNP production is lost at high frequency $(\sim 1 \%)$ by spontaneous mutations of genes, and its absence makes the cultures and colonies appear red and translucent (Figure 3, left panel). The color remaining in mutants is due to the presence of red-orange carotenoids, similar to those found in carrots, tomatoes, and sugar maple leaves (apparent in the fall) and in retinal (similar to the vitamin A needed for vision).

Gas-vesicle mutants may be the start of an experiential journey for students into the genotype-phenotype connection, especially when they encounter the variably colored colonies ("sectored colonies") that look like pies with multicolored slices (see Figure 3, left panel). Students can observe mutants in nearly any agar plate with a few hundred colonies of NRC-1. Differently colored colonies (including shades of red and pink, white, and even purple) or segments

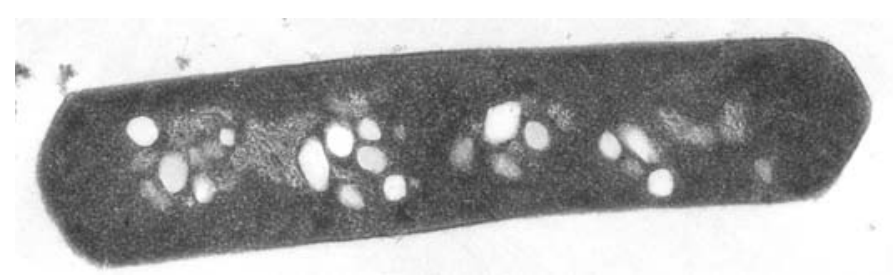

Figure 4. A single cell of NRC-1 is shown in an electron micrograph of a thin-section. The gas vesicles are the protein membranes surrounding the clear spaces. The cell is $\sim 2 \mu \mathrm{m}$ in length. Image by Shiladitya DasSarma. thereof can be picked (aided by a dissecting microscope or magnifying glass), cultured, and plated for further propagation and study.

\section{Deeper Inquiry into Genomics \& Bioinformatics}

The fast-paced fields of microbial genomics and bioinformatics are perhaps the most challenging to address in the classroom. The job is made simpler using the "Genotype-Phenotype Connection" kit, coupled with an easy method of nucleic-acid extraction that involves picking mutant colonies using pipet tips and lysing in hypotonic buffer containing PCR components. PCR amplification can be conducted on any of the 2500+ NRC-1 genes, such as any gas-vesicle protein ( $g v p$ ) gene, and the products analyzed on an agarose gel. Students can use HaloWeb, a custom website at the University of Maryland-Baltimore County, to access the NRC-1 genome for primer design and to predict PCR amplicon sizes (http://halo.umbc.edu; S. DasSarma et al., 2010). On the basis of published results, they can predict which insertion element was inserted into the gas-vesicle gene cluster (DasSarma, 1989).

For advanced classes with access to DNA sequencing capabilities, often possible through partnerships with a local university sequencing facility or commercial lab, students can have their PCR-amplified products sequenced. This will result in the data necessary to determine the nature of the mutation, including the precise identity of any ISH involved. Students are likely to discover how DNA rearrangements may occur during microbial variation and appreciate how these changes are related to changing environments. This exercise naturally leads to stimulating discussions, such as on Darwin's theory of evolution by natural selection. For example, would cells that have lost their gas vesicles (and buoyancy) survive in their harsh natural environment? Do culturing conditions in the lab have any effect on selection of cells containing (or lacking) gas vesicles? Is the maintenance of gas vesicles important for energy generation?

\section{O NRC-1: The New Model Microbe for Learning about Biotechnology}

The sequencing of NRC-1 provided the first Haloarchaeal genome at the turn of the millennium ( $\mathrm{Ng}$ et al., 2000), leading to a rapid expansion in the field of Haloarchaeal biotechnology. Many scientific careers and ventures have been spawned, including the use of Haloarchaea as cell factories for producing recombinant proteins, such as a plethora of enzymes for cold-wash laundry detergents that are contributing to environmentally conscious lifestyles. In the medical field, microbial retinal proteins are being used to visualize neuronal responses in vivo and in research toward curing blindness (Busskamp et al., 2010; Williams \& Deisseroth, 2013). The prototype membrane proteins, like bacteriorhodopsin, from NRC-1 and other Haloarchaea are being used for bioengineering biocomputer chips and making memory storage devices (Birge, 1995). GVNPs are also being used for delivery of therapeutic proteins and vaccines (P. DasSarma et al., 2010a, 2014; DasSarma \& DasSarma, 2015; Dutta et al., 2015; Pecher et al., 2016). These activities are accessible to students through literature and patent searches, allowing them to "discover" many exciting new innovations. 


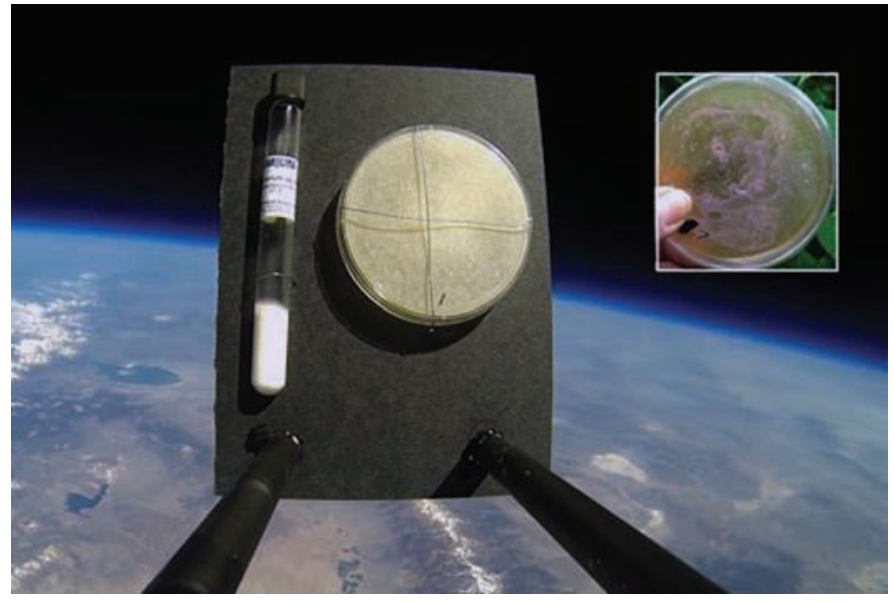

Figure 5. Halobacterium NRC-1 cells survive flight on board the payload of a suborbital helium balloon to the stratosphere, $>32 \mathrm{~km}$ above the Earth's surface, testing their resistance to Mars-like conditions. After experiencing temperatures as low as $-70^{\circ} \mathrm{C}$, air pressure only $1 \%$ that at sea level, and cosmic radiation fluxes $>25$ times Earth-normal, the microbes still grew (inset panel). Photo by Tony Phillips.

All the many biotechnological and medical advances, as well as the ongoing basic research on NRC-1 and other Haloarchaea, are a great inspiration for students to do science-fair or capstone projects (Table 1) and get first-hand experience in the fields of microbiology and microbial biotechnology. A few of the many recent, awardwinning student-led projects include the discovery of antimicrobial compounds, isolation of new Haloarchaeal strains, and the exploration of conditions that limit life. Another recent, exciting "classroom" project was the launching of NRC-1 into the stratosphere to test tolerance to Mars-like conditions near the edge of Earth's atmosphere and studying their responses upon return to Earth (Figure 5).

\section{O Conclusion}

As educators, our primary tasks are to help foster better understanding of nature and to nurture curiosity-driven exploration by our students. In microbiology classes, exercises using the versatile and colorful polyextremophilic microbe Halobacterium NRC-1 can launch students on a trajectory toward appreciating the tremendous diversity and numbers of microorganisms. While developing the traditional "hypothesis, experimentation, results and conclusions" scientific approach, they also learn the thrill of discovery and of thinking innovatively, outside the box. There is no better way for students to learn important concepts and valuable applications than by conducting their own experiential research, using this well-characterized, accessible, safe, and engaging model microbe.

\section{Acknowledgments}

Our work is supported through the Haloarchaeal Education and Research and Development Fund ("HERD," at http://halo.umbc. edu/haloed/donate) and nearly 30 years of continuous support of the DasSarma Laboratory from NASA, National Institutes of Health,
Gates Foundation, Henry M. Jackson Foundation, National Science Foundation, and Department of Energy. We thank the many students involved in Haloarchaeal research and development for their contributions.

\section{References}

Amábile-Cuevas, C.F. (2003). New antibiotics and new resistance. American Scientist, 91, 138-149.

Bayley, S.T. \& Morton, R.A. (1978). Recent developments in the molecular biology of extremely halophilic bacteria. CRC Critical Reviews in Microbiology, 6, 151-205.

Berquist, B.R., Müller, J.A., DasSarma, P. \& DasSarma, S. (2005). Genetic systems for halophilic Archaea. In A. Oren \& F. Rainey (Eds.), Methods in Microbiology (pp. 148-182). Amsterdam, The Netherlands: Elsevier/ Academic Press.

Birge, R.R. (1995). Protein-based computers. Scientific American, 272, 90-95.

Boubriak, I., Ng, W.L., DasSarma, P., DasSarma, S., Crowley, D.J. \& McCready, S.J. (2008). Transcriptional responses to biologically relevant doses of UV-B radiation in the model archaeon, Halobacterium sp. NRC-1. Saline Systems, 4, 13.

Busskamp, V., Duebel, J., Balya, D., Fradot, M., Viney, T.J., Siegert, S. et al. (2010). Genetic reactivation of cone photoreceptors restores visual responses in retinitis pigmentosa. Science, 329, 413-417.

Coker, J.A., DasSarma, P., Kumar, J., Müller, J.A. \& DasSarma, S. (2007). Transcriptional profiling of the model Archaeon Halobacterium sp. NRC-1: responses to changes in salinity and temperature. Saline Systems, 3, 6.

Crowley, D.J., Boubriak, I., Berquist, B.R., Clark, M., Richard, E., Sullivan, L. et al. (2006). The uurA, uurB and uurC genes are required for repair of ultraviolet light induced DNA photoproducts in Halobacterium sp. NRC-1. Saline Systems, 2, 11.

DasSarma, P. (2007). Halobacteria: making microbioloğy manageable. Carolina Biological Supply. Available online at http://www.carolina. com/teacher-resources/Interactive/halobacteria-makinģ-microbioloģymanageable/tr10761.tr.

DasSarma, P., Coker, J.A., Huse, V. \& DasSarma, S. (2010a). Halophiles, industrial applications. In M.C. Flickinger (Ed.), Encyclopedia of Industrial Biotechnology. New York, NY: Wiley.

DasSarma, P. \& DasSarma, S. (2008). On the origin of prokaryotic "species": the taxonomy of halophilic Archaea. Saline Systems, 4, 5.

DasSarma, P., Klebahn, G. \& Klebahn, H. (2010b). Translation of Henrich Klebahn's "Damaging agents of the klippfish - a contribution to the knowledge of the salt loving organisms." Saline Systems, 6, 7.

DasSarma, P., Neģi, V.D., Balakrishnan, A., Karan, R., Barnes, S., Ekulona, F. et al. (2014). Haloarchaeal gas vesicle nanoparticles displaying Salmonella SopB antigen reduce bacterial burden when administered with live attenuated bacteria. Vaccine, 32, 4543-4549.

DasSarma, P., Zamora, R.C., Müller, J.A. \& DasSarma, S. (2012). Genome-wide responses of the model archaeon Halobacterium sp. strain NRC-1 to oxygen limitation. Journal of Bacterioloǵy, 194, 5530-5537.

DasSarma, S. (1989). Mechanisms of genetic variability in Halobacterium halobium: the purple membrane and gas vesicle mutations. Canadian Journal of Microbiology, 35, 65-72.

DasSarma, S. (2006). Extreme halophiles are models for astrobiology. Microbe, 1, 120-127.

DasSarma, S. (2007). Extreme microbes. American Scientist, 95, 224-231.

DasSarma S.L., Capes, M.D., DasSarma, P. \& DasSarma, S. (2010). HaloWeb: the haloarchaeal genomes database. Saline Systems, 6, 12. Available online at http://halo.umbc.edu. 
DasSarma, S. \& DasSarma, P. (2015). Gas vesicle nanoparticles for antiggen display. Vaccines, 3, 686-702.

DasSarma, S. \& Fleischmann, E.M. (Eds.) (1995). Archaea: A Laboratory Manual - Halophiles. Cold Spring Harbor, NY: Cold Spring Harbor Laboratory Press.

DasSarma, S., Kennedy, S.P., Berquist, B., Nģ, W.V., Baliģa, N.S., Spudich, J.L. et al. (2001). Genomic perspective on the photobiology of Halobacterium species NRC-1, a phototrophic, phototactic, and UVtolerant haloarchaeon. Photosynthesis Research, 70, 3-17.

Dutta, S., DasSarma, P., DasSarma, S. \& Jarori, G.K. (2015). Immunogenicity and protective potential of a Plasmodium spp. Enolase peptide displayed on archaeal gas vesicle nanoparticles. Malaria Journal, 14, 406.

Karan, R., DasSarma, P., Balcer-Kubiczek, E., Wenģ, R.R., Liao, C.-C., Goodlett, D.R. et al. (2014). Bioengineering radioresistance by overproduction of RPA, a mammalian-type single-stranded DNA-binding protein, in a halophilic archaeon. Applied Microbiology and Biotechnology, 98, 1737-1747.

Khorana, H.G. (1972). Nucleic acid synthesis in the study of the genetic code. Nobel Lecture, December 12, 1968. In Nobel Lectures: Physiology or Medicine 1963-1970 (pp. 343-369). Amsterdam, The Netherlands: Elsevier.

Luria, S.E. (1975). 36 Lectures in Biologyy. Cambridge, MA: MIT Press.

McCarty, M. (1985). The Transforming Principle: Discovering That Genes Are Made of DNA. New York, NY: W.W. Norton.

Mormile, M.R., Biesen, M.A., Gutierrez, M.C., Ventosa, A., Pavlovich, J.B., Onstott, T.C. \& Fredrickson, J.K. (2003). Isolation of Halobacterium salinarum retrieved directly from halite brine inclusions. Environmental Microbiology, 5, 1094-1102.

Nog, W.V., Kennedy, S.P., Mahairas, G.G., Berquist, B., Pan, M., Shukla, H.D. et al. (2000). Genome sequence of Halobacterium species NRC-1. Proceedings of the National Academy of Sciences USA, 97, 12176-12181.

Pecher, W.T., Kim, J.-M., DasSarma, P., Karan, R., Sinnis, P. \& DasSarma, S. (2016). Halobacterium expression system for production of full-length Plasmodium falciparum circumsporozoite protein. In P.H. Rampelotto (Ed.), Biotechnology of Extremophiles: Advances and Challenges. Springer International.

Rothschild, L.J. \& Mancinelli, R.L. (2001). Life in extreme environments. Nature, 409, 1092-1101.

Slonczewski, J.L., Coker, J.A. \& DasSarma, S. (2010). Microbial growth under multiple stressors. Microbe, 5, 110-116.

Williams, S.C. \& Deisseroth, K. (2013). Optogenetics. Proceedings of the National Academy of Sciences USA, 110, 16287.

Woese, C.R. (1981). Archaebacteria. Scientific American, 244, 98-122.

PRIYA DASSARMA (pdassarma@som.umaryland.edu) specializes in teacher and student education, public outreach, and Haloarchaeal research at the Institute of Marine and Environmental Technology, Department of Microbiology and Immunology, University of Maryland, Baltimore, MD 21202. KELLEY TUEL (kel@tuel.us) teaches veterinary sciences at Blue Valley Center for Advanced Professional Studies in Overland Park, KS 66223.

SUSAN DEAN NIERENBERG (snierenberog@bcps.orģ) teaches biology and microbiology at Randallstown High School, Randallstown, MD 21133.

TONY PHILLIPS (dr.tony.phillips@ogmail.com) mentors high school students at Spaceweather.com in Bishop, CA 93514. WOLF THOMAS PECHER (wpecher@ubalt.edu) is an Assistant Professor and teaches environmental science and biotechnology at the University of Baltimore, Baltimore, MD 21201. SHILADITYA DASSARMA (sdassarma@som.umaryland.edu) is a Professor in Graduate Programs in Life Sciences and Marine, Estuarine, and Environmental Science, Institute of Marine and Environmental Technology, University of Maryland School of Medicine, Baltimore, MD 21202.
minıOne"

ELECTROPHORESIS

REVOLUTIONIZE

THE WAY YOU TEACH BIOTECHNOLOGY

\section{ENGAGING}

Engaging Students

Through Inquiry-Based Instruction

\section{HANDS-ON}

Hands-on Electrophoresis

Full Band Separation within 20 Minutes

\section{SAFE}

Safe 42V Power Supply

Blue LEDs for Visualization - UV Free

Non-hazardous GelGreen DNA Stain

\section{CONTACT US FOR A CUSTOM OUOTE}

C (858) 684-3190

$\nabla$ info@ theminione.com

(www.theminione.com 


\section{Are You REACHING Your Students?}

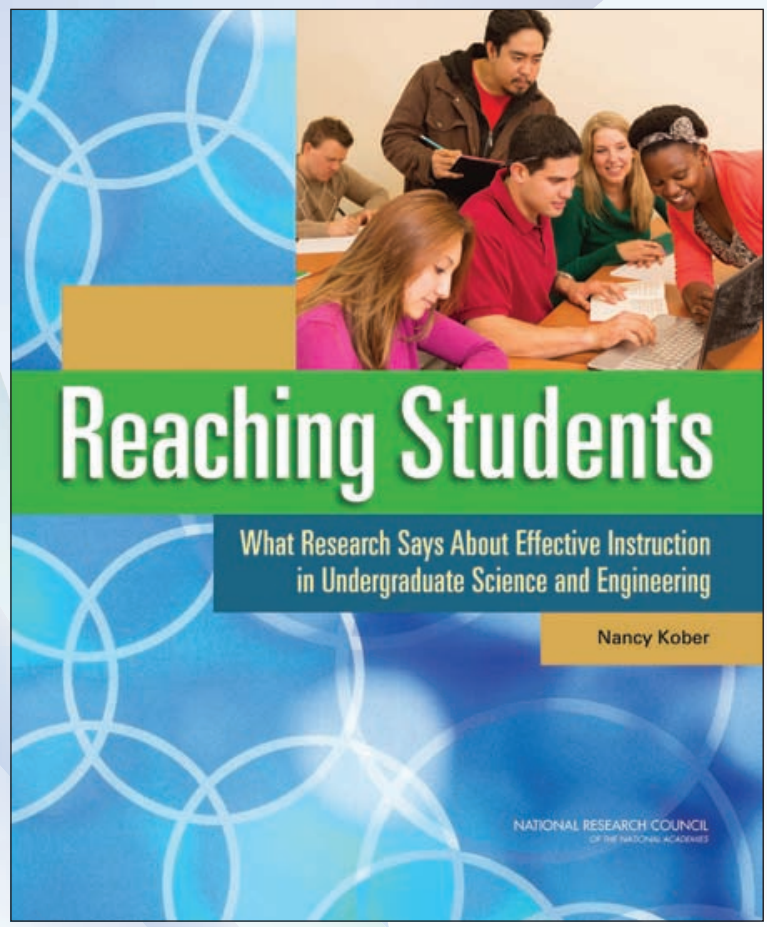

Reaching Students presents the best thinking to date on teaching and learning undergraduate science and engineering. Focusing on the disciplines of astronomy, biology, chemistry, engineering, geosciences, and physics, this book is an introduction to strategies to try in your classroom or institution. Concrete examples and case studies illustrate how experienced instructors and leaders have applied evidence-based approaches to address student needs, encouraged the use of effective techniques within a department or an institution, and addressed the challenges that arose along the way.

\section{Reaching Students}

What Research Says About Effective Instruction in Undergraduate Science and Engineering

ISBN 978-0-309-30043-8

$\$ 39.95$

Our reports discuss ways to use research-based findings and techniques to enhance student learning from kindergarten through post-graduate work. All are free to download or purchase in print.

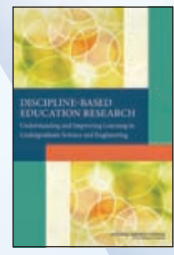

Discipline-Based Education Research Understanding and Improving Learning in Undergraduate Science and Engineering

ISBN 978-0-309-25411-3

$\$ 49.00$

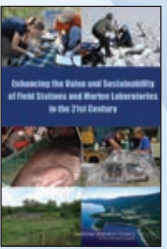

Enhancing the Value and Sustainability of Field Stations and Marine Laboratories in the 21st Century

ISBN 978-0-309-30534-1

$\$ 46.00$

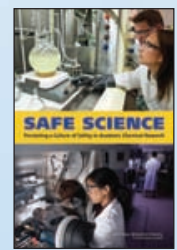

\section{Safe Science}

Promoting a Culture of Safety in Academic Chemical Research

ISBN 978-0-309-30091-9

$\$ 45.00$

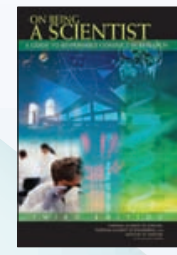

On Being a Scientist

A Guide to Responsible Conduct in Research Third Edition

ISBN 978-0-309-11970-2

$\$ 14.95$

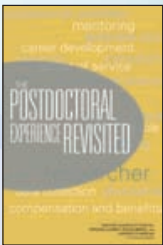

The Postdoctoral Experience Revisited

ISBN 978-0-309-31446-6

$\$ 49.95$

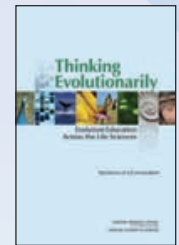

\section{Thinking Evolutionarily}

Evolution Education Across the Life Sciences

Summary of a Convocation

ISBN 978-0-309-25689-6

$\$ 36.00$ 